\title{
ANTIMICROBIAL ACTIVITY AND CHEMICAL CHARACTERIZATION OF LAUREL ESSENTIAL OIL
}

\author{
Juliana Olívia Nicolao ${ }^{1}$ \\ Franciana Aparecida Volpato Bellaver ${ }^{2}$ \\ Volmir Kirst ${ }^{10}$ \\ Daniel Radin ${ }^{1}$ \\ Marcelo Mendes de $\mathrm{Haro}^{3}$ \\ André Alois Nicolao ${ }^{4(0)}$ \\ Elis Regina Alchieri dos Santos ${ }^{5(0)}$ \\ Alessandra Farias Millezi ${ }^{1,2 *}$
}

NiCOlAO, J. O.; BEllaVER, F. A. V.; KIRST, V.; RADIN, D.; HARO, M. M. de; NICOLAO, A. A.; MiLlEZI, A. F. Antimicrobial activity and chemical characterization of Laurel essential oil. Arquivos de Ciências Veterinárias e Zoologia da UNIPAR, Umuarama, v. 24, n. 2cont., e2407, 2021.

\begin{abstract}
The factors that arouse interest in the study of essential oils as biocidal agents are numerous, such as the fact that they have antibacterial, antifungal, insecticidal, antioxidant, anti-inflammatory and larvicidal properties. The objective of this work was to evaluate the antimicrobial activity, in vitro, of the laurel (Laurus nobilis L) essential oil on the growth of pathogenic bacteria Salmonella enterica serovar Typhimurium ATCC 14028 and Staphylococcus aureus ATCC 25923, at different exposure times, as well as to perform the chemical characterization. Twenty compounds were identified and quantified, representing $96.57 \%$ of the total composition. The class of oxygenated monoterpenes represented the majority class of the essential oil, with 1,8-cineol (33.8\%) as the substance found in greater quantity, followed by linalool (17.79\%). The third constituent in greater quantity was sabinene (12.23\%), belonging to the group of monoterpene hydrocarbons. Terpinyl acetate (9.41\%) was also considered to be quantitatively representative. Laurel essential oil showed bacteriostatic activity against $S$. Typhimurium ATCC 14028 and $S$. aureus ATCC 25923.
\end{abstract}

KEYWORDS: Antibacterial. Salmonella Typhimurium. Staphylococcus aureus.

\section{ATIVIDADE ANTIMICROBIANA E CARACTERIZAÇÃO QUÍMICA DO ÓLEO ESSENCIAL DE LOURO}

RESUMO: Os fatores que despertam interesse no estudo dos óleos essenciais como agentes biocidas são inúmeros, como o fato de possuírem propriedades antibacteriana, antifúngica, inseticida, antioxidante, antiinflamatória e larvicida. O objetivo deste trabalho foi avaliar a atividade antimicrobiana, in vitro, do óleo essencial de louro (Laurus nobilis L) sobre o crescimento das bactérias patogênicas Salmonella enterica sorovar Typhimurium ATCC 14028 e Staphylococcus aureus ATCC 25923, em diferentes tempos de exposição, assim como realizar a caracterização química do óleo. Vinte compostos foram identificados e quantificados, representando $96,57 \%$ da composição total. A classe dos monoterpenos oxigenados representou a classe majoritária do óleo essencial, sendo o 1,8-cineol $(33,8 \%)$ a substância encontrada em maior quantidade, seguido do linalol (17,79\%). O terceiro constituinte em maior quantidade foi o sabineno (12,23\%), pertencente ao grupo dos hidrocarbonetos monoterpênicos. $\mathrm{O}$ acetato de terpinila $(9,41 \%)$ também foi considerado quantitativamente representativo. O óleo essencial de louro apresentou atividade bacteriostática contra $S$. Typhimurium ATCC 14028 e $S$. aureus ATCC 25923.

PALAVRAS CHAVE: Antibacteriano. Salmonella Typhimurium. Staphylococcus aureus.

\footnotetext{
DOI: 10.25110 /arqvet.v24i2cont.2021.8512

${ }^{1}$ Agronomy Course, Federal Catarinense Institute, Concordia Campus, Rodovia SC 283, s/n Fragosos, SC, 89703-720.

${ }^{2}$ Master in Animal Production and Health Course, Federal Catarinense Institute, Concordia Campus, Rodovia SC 283, s/n Fragosos, SC, 89703-720.

*correspondence author: alessandra.millezi@ifc.edu.br

${ }^{3}$ EPAGRI - Agricultural Research and Rural Extension Company of Santa Catarina, Parque Agricultor Gilmar Graf - R. Mansueto Felizardo Vieira, 557 - Baía, Itajaí - SC, 88318-076.

${ }^{4}$ Food Engineering Course, Federal Catarinense Institute, Concordia Campus, Rodovia SC 283, s/n Fragosos, SC, 89703-720.

${ }^{5}$ Food Technical Course, Federal Catarinense Institute, Concordia Campus, Rodovia SC 283, s/n Fragosos, SC, 89703-720.
} 


\section{ACTIVIDAD ANTIMICROBIANA Y CARACTERIZACIÓN QUÍMICA DEL ACEITE ESENCIAL DE LAUREL}

RESUMEN: Los factores que despiertan interés en el estudio de los aceites esenciales como agentes biocidas son innumerables, como el hecho de que tienen propiedades antibacterianas, anti fúngicas, insecticidas, antioxidantes, antiinflamatorias y larvicidas. El objetivo de este trabajo ha sido evaluar la actividad antimicrobiana, in vitro, del aceite esencial de laurel (Laurus nobilis L) sobre el crecimiento de bacterias patógenas Salmonella enterica serovar Typhimurium ATCC 14028 y Staphylococcus aureus ATCC 25923, en diferentes momentos de exposición, así como realizar la caracterización química del aceite. Se identificaron y cuantificaron veinte compuestos, que representan el $96,57 \%$ de la composición total. La clase de mono terpenos oxigenados representó la clase principal de aceite esencial, siendo el 1,8-cineol $(33,8 \%)$ la sustancia que se encuentra en mayor cantidad, seguida del linalol (17,79\%). El tercer constituyente en mayor cantidad fue el sabineno (12,23\%), perteneciente al grupo de los hidrocarburos monoterpénicos. El acetato de terpinilo $(9,41 \%)$ también se consideró cuantitativamente representativo. El aceite esencial de laurel mostró actividad bacteriostática contra $S$. Typhimurium ATCC 14028 y S. aureus ATCC 25923.

PALABRAS CLAVE: Antibacteriano. Salmonella Typhimurium. Staphylococcus aureus.

\section{Introduction}

Aromatic and medicinal plants have been used for thousands of years in different cultures around the world, especially because they contain essential oils, formed from secondary metabolic pathways and defined as complex mixtures of volatile, lipophilic, usually odoriferous and liquid substances (SIMÕES et al., 2004). In general, these oils contain about 20 to 60 components in different concentrations, characterized by two or three major compounds in high concentrations $(20-70 \%)$ compared to other components present in minimal amounts (BAKKALI et al., 2008).

Among the plants producing essential oils, the laurel, (Laurus nobilis L), belonging to the Lauraceae family, stands out, a tree native to the southern Mediterranean region, grown mainly in Europe and the USA, as an ornamental and medicinal plant (CAPUTO et al., 2017). Phytochemical investigations with this oil revealed the main presence of sesquiterpenes, phenolic compounds and flavonoids, which showed cytotoxic activities and inhibitory effects on alcohol absorption (CHEN et al., 2014).

The factors that arouse interest in the study of essential oils as biocidal agents are numerous, such as the fact that they have antibacterial, antifungal, insecticidal, antioxidant, anti-inflammatory and larvicidal pharmacological properties (ALEXOPOULOS et al., 2011; GUIMARÃES et al., 2011; PAULIQUEVIS; FAVERO, 2015; VALERIANO et al., 2012). These oils emerged as a control alternative to pathogenic strains resistant to conventional antibiotics and causing serious public health problems worldwide (ARAUJO; LONGO, 2016; HENSEL, 2004; VALERIANO et al., 2012). Among the main biological agents causing these pathologies are bacteria of the genus Salmonella spp. and Staphylococcus aureus, both transmitted by food and direct contact to humans and animals, causing several gastrointestinal infections (HENSEL, 2004).

Bacteria of the genus Salmonella are classified as Gram-negative, have a lipopolysaccharide component on their outer membrane and a cell wall composed of a thin layer of peptidoglycans. Most of its serotypes are pathogenic to man, as in the case of Salmonella enterica Enteretidis and Salmonella enterica Typhimurium, the main serovars responsible for causing salmonellosis; one of the main zoonoses for public health worldwide, generating a significant cost to society, due to the high endemicity, morbidity and difficulty in its control
(SHINOHARA et al., 2008).

Bacteria of the species $S$. aureus integrate part of the human microbiota and are classified as Gram-positive, do not contain lipopolysaccharide, but in compensation, have a thick layer of peptidoglycans. The infection by this pathogen presents a high risk to humans, due to the combination of antibiotic resistance and its virulence factors. When the infection happens associated with the weakened host's immune system, this bacterium is responsible for serious clinical pathologies, which can be fatal (OTTO, 2010). In addition, S. aureus produces thermostable toxins that can remain in the food even after cooking; among the food poisoning of bacterial origin in the world, about $45 \%$ are related to $S$. aureus (ARAUJO; LONGO, 2016).

The objective of this work was to carry out the chemical characterization of the laurel essential oil and to evaluate the antimicrobial activity, in vitro, on the growth of microorganisms $S$. Typhimurium ATCC 14028 and S. aureus ATCC 25923, at different times of exposure.

\section{Material and Methods}

\section{Location of the experiment}

The chemical characterization of the laurel essential oil was carried out at EMBRAPA Swine and Poultry in Concordia and microbiological analyzes were conducted at the Biology Laboratory, at the Federal Catarinense Institute (IFC) - Concordia.

\section{Collection of the material and exsiccate}

The plant material was collected in the Concórdia/SC. The collection took place at 7 am on April 10, 2017 and only the leaves of laurel were collected. Later, the dry vegetable was assembled in an exsiccate, which will be conserved at the Herbarium Padre Balduíno Rambo of URI in Erechim/RS, HPBR 12.087 Laurus nobilis L. (laurel), carrying a label with all the data of the collection form.

\section{Maintenance of bacteria and inoculum preparation}

The microorganisms used were Salmonella enterica serovar Typhimurium ATCC 14028 and Staphylococcus aureus ATCC 25923. The stock cultures were kept in a freezing medium, consisting of glycerol (DYNAMIC, BR) and Brain Heart Infusion (BHI) (BACTO ${ }^{\mathrm{TM}}$, USA), in the proportion 
1:1 at $-70^{\circ} \mathrm{C}$. The strains were reactivated in $\mathrm{BHI}$ (BACTO ${ }^{\mathrm{TM}}$, USA) broth with incubation at $37^{\circ} \mathrm{C}$ for $24 \mathrm{~h}$. The inoculum were standardized at $10^{8} \mathrm{CFU} \mathrm{mL} \mathrm{m}^{-1}$ after elaboration of growth curves (D.O. ${ }_{550 \mathrm{~mm}}$ ) in BHI (BACTO ${ }^{\mathrm{TM}}$, USA), plating in Tryptic Soy Agar (TSA) (NEOGEN, USA) and incubation at $37^{\circ} \mathrm{C}$ for $24 \mathrm{~h}$.

\section{Essential Oil Extraction}

To extract the laurel essential oil, the steam distillation method was used, in a pilot scale distiller made of stainless steel. About $5 \mathrm{~kg}$ of fresh vegetable material (aerial parts) were stored in the extraction system. The steam was generated in a boiler and conducted through the plant material to release the aromatic content. After condensation in a refrigerated coil, the aqueous phase was continuously transferred to a decanting funnel, where the essential oil was obtained by spontaneous separation of the phases. After two hours of extraction, the crude essential oil was transferred to a $50 \mathrm{~mL}$ tube containing $0.5 \mathrm{~g}$ of anhydrous $\mathrm{Na}_{2} \mathrm{SO}_{4}$ for total removal of the water particles. The sample was vortexed for 30 seconds and then centrifuged at $2000 \mathrm{~g}$ for 10 minutes at $5^{\circ} \mathrm{C}$. The clear essential oil was transferred to an amber glass bottle and stored at $-20^{\circ} \mathrm{C}$. The sample of essential oil (100mg) was dissolved in dichloromethane $(10 \mathrm{~mL})$ and the resulting solution was analyzed by gas chromatography (GC-FID and GC-MS) (CUNHA et al., 2013).

\section{Gas chromatography with flame ionization detection (GC- FID)}

The analysis of laurel essential oil was performed in an Agilent 7820A gas chromatograph (AGILENT TECHNOLOGIES, CN) equipped with a split/splitless injector, a flame ionization detector (FID) and an Agilent auto injector 7693A. The sample solution $(1 \mu \mathrm{l})$ was injected in split mode at a ratio of $1: 10$. The analyses were performed with an Agilent J\&W HP-5 capillary column (30m x $0.25 \mathrm{~mm}$ i.d., film with a thickness of $1 \mu \mathrm{m}$, stationary phase consisting of $5 \%$ diphenyl $/ 95 \%$ dimethylpolysiloxane). The oven temperature was maintained at $50^{\circ} \mathrm{C}$ for two minutes, increased from 50 to $220^{\circ} \mathrm{C}$ at a rate of $2^{\circ} \mathrm{C} / \mathrm{min}$ and maintained at $220^{\circ} \mathrm{C}$ for three minutes. Nitrogen 5.0 was used as carrier gas at a flow rate of $1.2 \mathrm{~mL} / \mathrm{min}$. The injector and detector temperatures were set at $240^{\circ} \mathrm{C}$ and $280^{\circ} \mathrm{C}$, respectively. The air flows, $\mathrm{H}_{2}$ and $\mathrm{N}_{2}$ in the detector were 300,30 and $30 \mathrm{~mL} / \mathrm{min}$. The OpenLAB CDS software was used for equipment management and data processing. The composition of the essential oil was expressed as a percentage of normalized area (ADAMS, 2001; CUNHA et al., 2013).

\section{Gas chromatography coupled to mass spectrometry (CG-} MS)

The essential oil was analyzed in a gas chromatograph coupled to a Shimadzu GCMS-QP2010 mass spectrometer equipped with a split/splitless injector. The sample solution $(1 \mu \mathrm{l})$ was injected in split mode at a ratio of 1:10. The analyses were performed with a Supelco Equity-5 capillary column (30m $\times 0.2 \mathrm{~mm}$ i.d., film with a thickness of $0.2 \mu \mathrm{m}$, stationary phase consisting of 5\% diphenyl/95\% dimethylpolysiloxane).
The oven temperature was maintained at $50^{\circ} \mathrm{C}$ for 2 minutes, increased from 50 to $220^{\circ} \mathrm{C}$ at a rate of $2^{\circ} \mathrm{C} / \mathrm{min}$ and maintained at $220^{\circ} \mathrm{C}$ for 3 minutes. Helium 5.0 was used as carrier gas at a flow rate of $1.2 \mathrm{ml} / \mathrm{min}$ (constant linear speed of $39.2 \mathrm{~cm} / \mathrm{s}$ ). The injector temperature was fixed at $240^{\circ} \mathrm{C}$. The interface and ion source temperatures were set at 220 and $200^{\circ} \mathrm{C}$, respectively. The quadrupole mass spectrometer was operated in $70 \mathrm{~V}$ electronic impact mode with scanning in the range of $m / z 35-350$ in 0.5 s cycles. The GCMS solution software was used for equipment management and data processing. The compounds were identified by searching the NIST 05 mass spectrum library and comparing their retention indices for the $\mathrm{C} 7-\mathrm{C} 30$ alkane series with those found in the literature (ADAMS, 2001; CUNHA et al., 2013).

\section{Essential oil-based solutions}

The $2.5 \%$ essential oil stock solution was prepared using as diluent $0.16 \mu \mathrm{L}$ of $2 \%$ absolute ethyl alcohol PA (LABIMPEX, BR), $7.68 \mathrm{~mL}$ of $0.85 \%$ saline water with addition of tween 80 to $0.5 \%$ (v/v) (DINAMICA, BR) and $0.2 \mu \mathrm{L}$ of laurel essential oil (MILLEZI et al., 2016). From the stock solution, working solutions were prepared in different concentrations, being $0.4 \%(1.28 \mathrm{~mL}$ of stock solution and $2.72 \mathrm{~mL}$ of BHI (BACTO ${ }^{\mathrm{TM}}$, USA), $0.8 \%$ (2.56mL of stock solution and $1.44 \mathrm{~mL}$ of $\mathrm{BHI}$ and $1.0 \%(3.2 \mathrm{~mL}$ of stock solution and $0.8 \mathrm{~mL}$ of BHI.

\section{Bacterial death curve}

To evaluate the influence of the different concentrations of the laurel essential oil on the strains of $S$. aureus ATCC 25923 and S. Typhimurium ATCC 14028, the bacterial inoculum standardized at approximately $10^{8} \mathrm{CFU} /$ $\mathrm{mL}$ was transferred to 12 sterile falcon tubes, containing the different concentrations of essential oil and the control (without the essential oil, containing only the standardized inoculum in BHI medium (BACTO ${ }^{\mathrm{TM}}$, USA). Then, they were incubated in an orbital shaker (TECNAL, BR) at $37^{\circ} \mathrm{C}$, stirring at $80 \mathrm{rpm}$ for $24 \mathrm{~h}$. In addition, controls were made containing sterile distilled water to replace the corresponding aliquots of essential oil of each concentration, submitted to the same procedure. After $0.5 ; 1 ; 2 ; 4 ; 6 ; 8 ; 10$ and $12 \mathrm{~h}$ of exposure at a temperature of $37^{\circ} \mathrm{C}$, aliquots of $100 \mu \mathrm{L}$ of the samples were transferred to microtubes containing $900 \mu \mathrm{L}$ of distilled water, with serial dilutions and subsequent plating in TSA medium (NEOGEN, USA). The quantification of Colony Forming Units (CFU) was performed after 18-24 h. of incubation at $37^{\circ} \mathrm{C}$.

\section{Experimental design and statistical analysis}

The experimental design used was completely randomized (DIC). The data obtained were analyzed using generalized linear models (GLM) and the means compared by the Tukey test at $5 \%$ probability. The analyzes were performed in the R program, using the agricultural package and lme4 (BATES et al., 2015).The experimental tests were performed in triplicate with three repetitions. 


\section{Results}

The characterization of laurel essential oil identified 20 compounds, totaling $96.57 \%$ of the composition (Table 1). Among the identified compounds, there was a predominance of the terpenoid class $(92.47 \%)$, comprising oxygenated monoterpenes (64.99\%), monoterpene hydrocarbons $(26.22 \%)$ and sesquiterpene hydrocarbons (1.26\%). Additionally, compounds of the class of phenylpropanoids (4.1\%) were identified. Among oxygenated monoterpenes, 1,8-cineol $(33.8 \%)$ stood out as the substance found in greater quantity, followed by linalool $(17.79 \%)$. The third constituent in greater quantity was sabinene $(12.23 \%)$, belonging to the group of monoterpene hydrocarbons. Terpinyl acetate $(9.41 \%)$ was also considered to be quantitatively representative.

Table 1: Chemical composition (\% in normalized area) and yield of laurel essential oil

\begin{tabular}{|c|c|c|}
\hline Compounds $^{\mathrm{a}}$ & R.I. ${ }^{\mathbf{b}}$ & Area $(\%)$ \\
\hline$\alpha$-Thujene & 924 & 0.51 \\
\hline$\alpha$-Pinene & 929 & 4.53 \\
\hline Camphene & 943 & 0.1 \\
\hline Sabinene & 969 & 12.23 \\
\hline$\beta$-Pinene & 972 & 4.15 \\
\hline$\beta$-Mircene & 990 & 1.26 \\
\hline$\delta$-3-Carene & 995 & 0.42 \\
\hline$\delta$-4-Carene & 1014 & 0.34 \\
\hline$(+)$-Sylvestrene & 1025 & 2.51 \\
\hline 1.8-Cineol & 1029 & 33.8 \\
\hline (E)- $\beta$-Ocimene & 1046 & 0.17 \\
\hline$\gamma$-Terpineno & 1055 & 0.71 \\
\hline Linalool & 1101 & 17.79 \\
\hline 4-Terpineol & 1174 & 1.0 \\
\hline$\alpha$-Terpineol & 1188 & 2.28 \\
\hline terpinyl acetate & 1315 & 9.41 \\
\hline Eugenol & 1355 & 0.83 \\
\hline$\beta$-Elemene & 1388 & 0.5 \\
\hline Eugenol methyl ether & 1405 & 3.27 \\
\hline$\beta$-Caryophyllene & 1407 & 0.76 \\
\hline
\end{tabular}

Monoterpene Hydrocarbons

Oxygenated monoterpenes

Sesquiterpene hydrocarbons

Phenylpropanoids 4.1

Total identified (\%)

96.57

a The compounds are listed in order of elution on a Supelco Equity-5 column.

${ }^{\mathrm{b}}$ Retention index experimentally determined on a Supelco Equity-5 column using a homologous series of aliphatic hydrocarbons (C7C30)
The concentrations of laurel essential oil tested against $S$. Typhimurium ATCC 14028 bacteria showed a significant reduction in the bacterial population compared to the control (Figure 1a). Comparing the inhibitory action of concentrations, it is observed that 0.8 and $1.0 \%$ were more effective in reducing the number of bacteria cells than the $0.4 \%$ concentration (Figure 1a).

Similarly, cells of $S$. aureus ATCC 25923 exposed to different concentrations of laurel essential oil showed a reduction in bacterial population when compared to the control. There was a significant difference between treatments, with concentrations of 0.8 and $1.0 \%$ performing better than concentrations of $0.4 \%$ (Figure 1b).

Figure 1: Box plot indicating the effect of laurel essential oil concentrations on (a) Salmonella enterica ser Typhimurium ATCC 14028 and (b) Staphylococcus aureus ATCC 25923 cells.
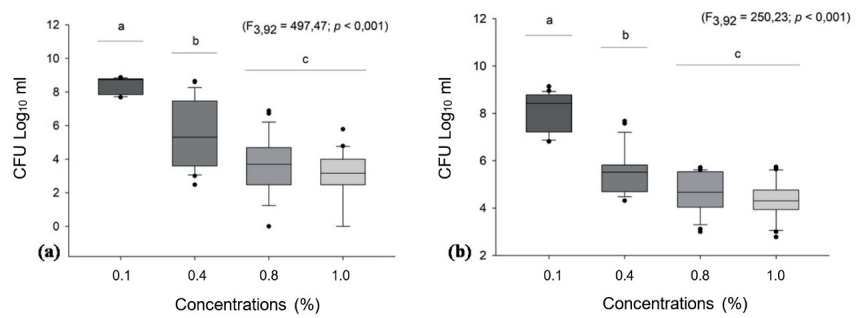

Means followed by the same letter do not differ, using the Tukey test $(p>0.05)$.

Analyzing time only, the laurel essential oil significantly reduced the population of $S$. Typhimurium ATCC 14028 by up to $2 \mathrm{~h}$ of experiment, with a mean of less than 0.5 h (Table 2). The reduction in the microbial load of $S$. aureus occurred up to $8 \mathrm{~h}$, with a lower mean at $4 \mathrm{~h}$. (Table 2).

Table 2: Effect of time in reducing the mean number of Colony Forming Units (CFU) ( \pm EP).

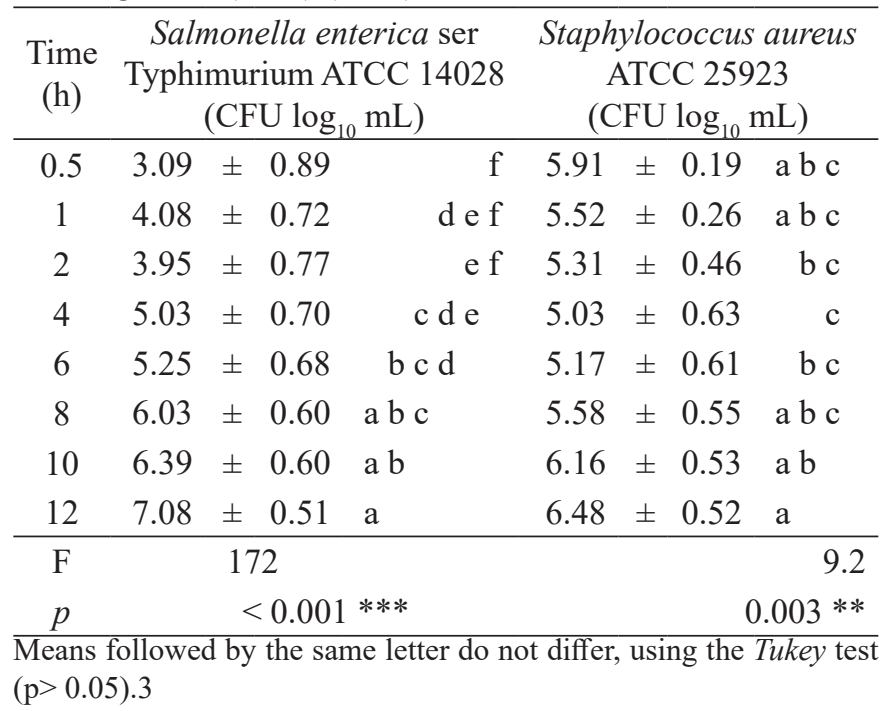




\section{Discussion}

The yield and chemical composition of essential oils can vary significantly, according to a number of factors, such as the stage of the plant's vegetative cycle, the plant's chemotype (chemical race), environmental factors such as altitude, temperature, relative humidity, time of sun exposure, presence of micronutrients and even the wind regime to which the plant is submitted (FIDAN et al., 2019; OUSSALAH et al., 2007). In addition, variations can also occur depending on the part of the plant that is used for extraction (KOVACEVIC et al., 2007).

In our study, we found as major components the compounds 1.8-cineol (33.8\%), linalool (17.79\%), sabinene $(12.23 \%)$ and terpinyl acetate $(9.41 \%)$. These compounds belong to the class of terpenes, reported as efficient antimicrobials, are likely to interfere with cell wall biosynthesis and ionic permeability of the membrane (PEIXOTO et al., 2017). In the analysis of the laurel fresh leaves oil, AlKalaldeh, Abu-Dahab and Afifi (2010) argued that 1,8-cineol (eucalyptol) (40.91\%) was the main component. Additionally, Guenane et al. (2017) also described 1,8-cineol (44.13\%) as a major compound, in addition to $\alpha$-terpinyl acetate $(17.33 \%)$ and methyl eugenol (6.53\%). Caputo et al. (2017), identified 1,8-cineol (31.9\%), sabinene (12.2\%) and linalool (10.2\%) as constituents in greater abundance.

The reduction in the bacterial population caused by the laurel essential oil can be attributed to the presence of these oxygenated monoterpenes, such as 1,8-cineol and linalool, present in greater quantities in this study, which have been shown to increase the antimicrobial activity of essential oils and antiseptics (BELLAVER et al, 2022; HERMAN et al., 2016; SIMSEK; DUMAN, 2017). Constituents of this class have demonstrated antibacterial activity against Gram-positive and Gram-negative (ROCHA et al., 2018; ROJAS et al., 2010). In addition, minority compounds can also contribute significantly to the antimicrobial activity of essential oils, since in vitro tests demonstrate that isolated compounds have less activity compared to essential oil (BURT, 2004; MILLEZI et al., 2019).

The use of essential oils against bacteria is justified due to its cytotoxic activity (BAKKALI et al., 2008). This effect is dependent not only on the chemical composition, but also on the state of division of the pathogenic organism (BAKKALI et al., 2008). Furthermore, because they are lipophilic compounds, these constituents act: crossing the cell wall and membrane, causing its permeability; as a consequence, it is observed the extraction of cellular materials such as ATP and nucleic acids; inducing coagulation of the cytoplasm; and damaging the lipids and proteins, leading to cell lysis (BAKKALI et al., 2008; RAUT; KARUPPAYIL, 2014).

The essential oil showed considerable activity against the bacteria studied, occurring to the reduction of bacterial cells, however, over $12 \mathrm{~h}$, there is a resumption of bacterial growth, which can be attributed to the volatile properties present in the essential oil, in addition to the solution $\mathrm{pH}$, treatment temperature and concentrations and type of active components Burt (2004). In addition, it is known that the range of action of essential oils against bacteria can reach values that result in a decline in the number of bacterial cells (bactericidal) or that inhibit only bacterial growth (bacteriostatic). The bactericidal action has a permanent effect, even after the neutralization of the agent, the microbial cells are not able to grow and reproduce; in contrast, the bacteriostatic has a reversible character, because after the neutralization of the agent, the microbial cells recover their reproductive capacity (FALEIRO, 2011). It is believed that in the present study, the action was bacteriostatic, as the cells resumed their growth after a certain time.

In the literature, similar results were found, which showed that essential oils are effective in inhibiting both Grampositive and Gram-negative bacteria (DORMAN; DEANS, 2000; MILLEZI et al. 2019; SZCZEPANSKI; LIPSKI, 2013; ZHANG et al., 2018). For Siriken et al. (2018), the strong antibacterial activity of laurel against Gram-negative and Gram-positive, was intensified with the use of zinc oxide nanoparticles (Ln-ZnO NPs). For Burt (2004), Gram-positive bacteria have been less or equally sensitive to Gram-negative bacteria. However, Oussalah et al. (2007) report that Grampositive bacteria are more sensitive to essential oils than Gram-negative bacteria. Corroborating this study, Caputo et al. (2017) show that the laurel essential oil showed bacteriostatic activity against $S$. aureus and in bacteria classified as Gramnegative.

The concentrations tested despite inhibiting the growth of $S$. Typhimurium ATCC 14028 and S. aureus ATCC 25923, did not fully reduce the Colony Forming Units (CFU/ $\mathrm{mL}$ ) over the $12 \mathrm{~h}$ of experiment. According to the literature, meat contamination levels around $10^{6} \mathrm{CFU} / \mathrm{cm}$ may indicate the beginning of the deterioration process with the production of unpleasant odor and compromised shelf life (FRANCO; LANDGRAF, 2005). In the case of $S$. aureus, the interval considered significant to cause food poisoning is $10^{5}-10^{6} \mathrm{CFU} /$ $\mathrm{mL}$; unsatisfactory hygienic-sanitary conditions are one of the most likely hypotheses for verifying contamination (SIMEÃO et al., 2002). Data from ICMSF (1998) corroborate showing that concentrations of this microorganism above $10^{5} \mathrm{CFU} /$ $\mathrm{ml}$ of product are considered sufficient for the production of staphylococcal toxins at levels propitious to food poisoning. In the case of Salmonella spp., the infective dose to healthy humans ranges from $10^{6}$ to $10^{8} \mathrm{CFU}$, although food salmonellosis at much lower doses has been reported Humphrey (2004).

\section{Conclusion}

Based on the exposed herein, the concentrations of 0.8 and $1.0 \%$ showed a significant reduction in the bacterial population, suggesting that they can be used for more in-depth tests, with other methodologies. There is the possibility of using the studied essential oil, in the production of chemical detergents or disinfectants, alternative controls to microorganisms, use in dairy products, in the cleaning of milking, pens and drinking fountains used in animal feed. Also, essential oils are natural products, they do not harm the environment. 
Acknowledgments

To the Instituto Federal Catarinense for the financial support of the project approved in announcement $n^{0} 130 / 2018$ and 39/2020, Support for Integrated Education, Research, and Extension projects applied to the Local Production, Cultural, and Social Arrangements in the IFC Campuses. To Embrapa Swine and Poultry.

Conflicts of Interest: The authors declare no conflict of interest.

\section{References}

ADAMS, R. Identification of essential oils componets by gas chromatography/quadrupole mass spectroscopy. $3^{\circ} \mathrm{ed}$. Carol Stream, Ill.: Allured Pub. Corporation, 2001.

AL-KALALDEH, J. Z.; ABU-DAHAB, R.; AFIFI, F. U. Volatile oil composition and antiproliferative activity of Laurus nobilis, Origanum syriacum, Origanum vulgare, and Salvia triloba against human breast adenocarcinoma cells. Nutrition Research, v. 30, n. 4, p. 271-278, 2010.

ALEXOPOULOS, A. et al. Antibacterial activities of essential oils from eight Greek aromatic plants against clinical isolates of Staphylococcus aureus. Anaerobe, v. 17, n. 6, p. 399-402, 2011.

ARAUJO, M. M. DE; LONGO, P. L. Teste da ação antibacteriana in vitro de óleo essencial comercial de Origanum vulgare (orégano) diante das cepas de Escherichia coli e Staphylococcus aureus. Arquivos do Instituto Biológico, v. 83, n. 0, p. 1-7, 2016.

BAKKALI, F.; AVERBECK, S.; AVERBECK, D.; IDAOMAR, M. Biological effects of essential oils - A review. Food and Chemical Toxicology, v. 46, n. 2, p. 446-475, 2008.

BATES, D.; MÄCHLER, M.; BOLKER, B.; WALKER, S. Fitting Linear Mixed-Effects Models Using lme4. Journal of Statistical Software, v. 67, n. 1, 2015.

BELLAVER, F. A. V; JUNIOR, A. C.; BELLO, T. C. D.; NEIS, A. J. L; TRONCARELLI M. Z.; MILLEZI, A. F. Antibacterial potential of essential oils against planktonic and sessile cells of Escherichia coli isolated from diarrhea cases in swine. Boletín Latinoamericano y del Caribe de Plantas Medicinales y Aromáticas, v. 21,n. 1, p. 81 - 93, 2022.

. BURT, S. Essential oils: Their antibacterial properties and potential applications in foods - A review. International Journal of Food Microbiology, v. 94, n. 3, p. 223-253, 2004.

CAPUTO, L. et al. Laurus nobilis: Composition of essential oil and its biological activities. Molecules, v. 22, n. 6, p. 1-11,
2017.

CHEN, H. et al. Sesquiterpenes Inhibiting the Microglial Activation from Laurus nobilis. Journal of Agricultural and Food Chemistry, v. 62, n. 20, p. 4784-4788, 2014.

CUNHA, A. et al. Synthesis and characterization of ethylic biodiesel from animal fat wastes. Fuel, v. 105, p. 228-234, 2013.

DORMAN, H. J. D.; DEANS, S. G. Antimicrobial agents from plants: Antibacterial activity of plant volatile oils. Journal of Applied Microbiology, v. 88, n. 2, p. 308-316, 2000 .

FALEIRO, M. L. The mode of antibacterial action of essential oils. Science against microbial pathogens: communicating current research and technological advances, v. 3, n. 3, p. 1143-1156, 2011.

FIDAN, H. et al. Chemical Composition and Antimicrobial Activity of Laurus nobilis L. Essential oils from Bulgaria. Molecules, v. 24, n. 4, p. 1-10, 2019.

FRANCO, B.; LANDGRAF, M. Microbiologia dos alimentos. São Paulo: Atheneu, 2005.

GUENANE, H. et al. Antioxidant capacity, mineral content and essential oil composition from select algerian medicinal plants. Scientific Study and Research: Chemistry and Chemical Engineering, Biotechnology, Food Industry, v. 18, n. 3, p. 275-289, 2017

GUIMARÃES, L. G. DE L.; CARDOSO, M. DAS G.; SOUSA, P. E. DE; ANDRADE, J. DE; VIEIRA, S. S. Atividades antioxidante e fungitóxica do óleo essencial de capim-limão e do citral. Revista Ciência Agronômica, v. 42, n. 2, p. 464-472, 2011.

HENSEL, M. Evolution of pathogenicity islands of Salmonella enterica. International Journal of Medical Microbiology, v. 294, n. 2-3, p. 95-102, 2004.

HERMAN, ANNA; TAMBOR, K.; HERMAN, ANDRZEJ. Linalool Affects the Antimicrobial Efficacy of Essential Oils. Current Microbiology, v. 72, n. 2, p. 165-172, 2016.

HUMPHREY, T. Salmonella, stress responses and food safety. Nature Reviews Microbiology, v. 2, n. 6, p. 504-509, 2004.

ICMSF. Microrganismos de los alimentos. Características de los patógenos microbianos. Zaragoza: Editorial Acribia, S.A., 1998.

KOVACEVIC, N. N.; SIMIC, M. D.; RISTIC, M. S. Essential oil of Laurus nobilis from Montenegro. Chemistry of Natural Compounds, v. 43, n. 4, p. 408-411, 2007. 
MILLEZI, A. F. et al. Antibacterial and anti-biofilm activity of cinnamon essential oil and eugenol. Ciencia Rural, v. 49, n. 1, p. 1-7, 2019.

MILLEZI, A. F.; PICCOLI, R. H.; OLIVEIRA, J. M.; PEREIRA, M. O. Anti-biofim and Antibacterial Effect of Essential Oils and Their Major Compounds. Journal of Essential Oil-Bearing Plants, v. 19, n. 3, p. 624-631, 2016.

OTTO, M. Basis of virulence in community-associated methicillin-resistant Staphylococcus aureus. Annual Review of Microbiology, v. 64, p. 143-162, 2010.

OUSSALAH, M.; CAILLET, S.; SAUCIER, L.; LACROIX, M. Inhibitory effects of selected plant essential oils on the growth of four pathogenic bacteria: E. coli O157:H7, Salmonella Typhimurium, Staphylococcus aureus and Listeria monocytogenes. Food Control, v. 18, n. 5, p. 414-420, 2007.

PAULIQUEVIS, C. F.; FAVERO, S. Atividade insetistática de óleo essencial de Pothomorphe umbellata sobre Sitophilus zeamais. Revista Brasileira de Engenharia Agrícola e Ambiental, v. 19, n. 12, p. 1192-1196, 2015.

PEIXOTO, R.; ROSALEN, P. L.; FERREIRA, G. L. S.; FREIRES, I. A.; DE CARVALHO, F. G.; CASTELLANO, L. R.; DE CASTRO, R. D. Antifungal activity, mode of action and anti-biofilmeffects of Laurus nobilis Linnaeus essential oil against Candida spp. Archives of Oral Biology, v. 73, p. 179-185, 2017.

RAUT, J. S.; KARUPPAYIL, S. M. A status review on the medicinal properties of essential oils. Industrial Crops and Products, v. 62, p. 250-264, 2014. Disponível em: <http:// dx.doi.org/10.1016/j.indcrop.2014.05.055>. .

ROCHA, E. O. et al. Chemical composition and antimicrobial activity of essential oil of flowers from Banisteriopsis campestris (A. Juss.) little. Revista Virtual de Quimica, v. 10, n. 5, p. 1562-1577, 2018.

ROJAS, L. B. et al. Composición química y efecto antibacteriano del aceite esencial de Aloysia triphylla (L'Hér.) Britton contra patógenos genito-urinarios. Boletin Latinoamericano y del Caribe de Plantas Medicinales y Aromaticas, v. 9, n. 1, p. 56-62, 2010.

SHINOHARA, N. K. S. et al. Salmonella spp., importante agente patogênico veiculado em alimentos. Ciência \& Saúde Coletiva, v. 13, n. 5, p. 1675-1683, 2008.

SIMEÃO, C. L. et al. Food poisoning due to enterotoxigenic strains of Staphylococcus present in Minas cheese and raw milk in Brazil. Food Microbiology, v. 19, n. 1, p. 9-14, 2002.

SIMÕES, C.; SCHENKEL, E.; GOSMANN, G. Óleos voláteis. Farmacognosia: da planta ao medicamento. $5^{\circ} \mathrm{ed}$. Porto Alegre: UFRGS. p.467-495, 2004.
SIMSEK, M.; DUMAN, R. Investigation of effect of 1,8-cineole on antimicrobial activity of chlorhexidine gluconate. Pharmacognosy Research, v. 9, n. 3, p. 234-237, 2017.

SIRIKEN, B.; YAVUZ, C.; GULER, A. Antibacterial activity of Laurus nobilis: a review of literature. Medical Science and Discovery, v. 90, n. 438, p. 374-379, 2018.

SZCZEPANSKI, S.; LIPSKI, A. Essential oils show specific inhibiting effects on bacterial biofilm formation. Food Control, v. 36, n. 1, p. 224-229, 2013.

VALERIANO, C. et al. Atividade antimicrobiana de óleos essenciais em bactérias patogênicas de origem alimentar. Revista Brasileira de Plantas Medicinais, v. 14, n. 1, p. 57 67, 2012.

ZHANG, X.; GUO, Y.; GUO, L.; JIANG, H.; JI, Q. In vitro evaluation of antioxidant and antimicrobial activities of Melaleuca alternifolia essential oil. BioMed Research International, v. 2018, 2018. 